\title{
Our Class: XIV Lessons from History (Nasza klasa: historia w XIV lekcjach)
}

Author: Tadeusz Słobodzianek

First Published: 2009

Translations: English (Our Class, 2009); German (Unsere Klasse, 2012); Czech (Naše tř́da, 2012); French (Notre Classe, 2015); Swedish (Vår klass, 2012) and many other languages.

Theatre Adaptations: Reading premiere: Theatre Confrontations Festival (Konfrontacje Teatralne), Lublin (2008). World premiere: London National Theatre (2009). Polish theatre premiere: Na Woli Theatre, Warsaw (2010). Other theatre adaptations (selected): Studio 189 Theatre, Toronto (2011); Lliure de Gràcia Theatre, Barcelona (2011); Katona Theatre, Budapest (2011); Bungaku-za Theatre, Tokyo (2012); Son of Semele Ensemble, Los Angeles (2013); PICT Theatre, Pittsburgh (2013); Galeasen Theatre, Stockholm (2013); Núcleo Experimental Theatre, São Paulo (2013); Lithuanian National Drama Theatre, Vilnius (2013); Cameri and Habima Theatres, Tel Aviv (2014) and many others.

About the Author: Tadeusz Słobodzianek (1955) was born in Yeniseysk (Krasnoyarsk Krai, Siberia, Russia), where his parents were deported during World War II. After the war his family moved to Białystok, Poland, a city whose multicultural climate has had a decisive influence on Słobodzianek's work. Słobodzianek's family was bi-religious: his mother was an Orthodox Jew and his father an anti-clerical Catholic. The author studied theatre at the Jagiellonian University in Cracow, the most important theatrical centre in Poland of the 1970s and 1980s. In those years Słobodzianek wrote theatre reviews for the weekly Polityka under the pseudonym Jan Koniecpolski. His career as a drama writer began in 1981 with the production of his children's play Autumn Tale (Baśń jesienna) in Wojciech Bogusławski's Theatre in Kalisz, and would make his debut as a director in the same theatre with Miron Białoszewski's drama (The Chagriners [Osmędeusze]). In the years that followed, he collaborated with theatres in a number of cities, including Warsaw, Cracow, Lodz, Poznan, Gdansk, and (with the city's puppet theatre) Białystok. In 1991, Słobodzianek founded the Wierszalin Theatre in Supraśl, near Białystok. He was also a lecturer in the Department of Journalism at Warsaw University. In 2003, Słobodzianek founded the Drama Laboratory in Warsaw, which has produced more than forty premieres, and is the first drama school in Poland with an emphasis on new playwrights.

Further Important Publications (all plays): Obywatel Pekosiewicz (Citizen Pekosiewicz, 1989); Turlajgroszek (Rolling Peas, 1991); Prorok Ilja (Prophet Ilya, 1991); Merlin - inna

Ә Open Access. () 2021 Agata Firlej, published by De Gruyter. (cc) BY-NC-ND This work is licensed under a Creative Commons Attribution-NonCommercial-NoDerivatives 4.0 License.

https://doi.org/10.1515/9783110671056-074 
historia (Merlin, The Secret History, 1993); Kowal Malambo (The Blacksmith Malambo, 1993); Sen pluskwy czyli towarzysz Chrystus (Bedbug's Dream, or Comrade Christ, 2000); Śmierć proroka i inne historie o końcu świata (The Prophet's Death And Other Stories about the End of the World (2012).

\section{Content and Interpretation}

Our Class is inspired by the incidents in Jedwabne village on 10 July 1941, at the beginning of World War II, when a group of forty Polish villagers murdered nearly 1,600 of their Jewish neighbours. The play is also influenced by Tadeusz Kantor's works, in particular The Dead Class. The story of Our Class, which is told from a child's point of view combined with adult commentary, follows a group of Polish and Jewish schoolmates as they head to class, only to end as victims and perpetrators of the massacre.

As the play opens, the setting is a school room with five school benches, but the pupils are dressed in adult outfits - the same outfits in which they will later die: Dora in a dress from the forties, Menachem in the uniform of an Israeli soldier, Heniek in a cassock, etc. Each character tells the story of her/his life and death: a rape scene, a wedding night, a military engagement, scenes of torture, the loss of children, antisemitic stereotypes, and finally their own collective murder. The stories are told candidly and without self-censorship - Dora, for example, reveals that she experienced some sexual pleasure while being raped -, but also without drama or emotion. It is a work that challenges common patterns of social behaviour, as well as the prescribed ways of remembering Shoah victims and perpetrators, presenting an example of the end of communicative memory, according to Jan Assmann's definition, when the last participants of the events are dead and their story belongs to the area of common cultural memory (see Lumír Čivrný's $\rightarrow$ The Black Tree's Memory). If a central mechanism of the play is catharsis, we are compelled to ask: on what basis does this catharsis play out? Is it the mechanism of identification and emotional purification, or merely a relief that the story has been told, so that there is no longer any need to think about it? As Myron Meisel writes in The Hollywood Reporter,

What begins as the mawkish loyalties of schoolmates degenerates into such a deep moral morass that even noble actions have base motifs, and in fact what everyone shares is not the bonds of affection but the imperatives of survival and the malice of greed. If the story of the Exodus must be told annually at Passover, there is little reason not to retell that of the Shoah at least as often, and to have it explored by a Polish writer has particular value as expiation. (Meisel, 2013)

\section{Main Topics and Problems}

Our Class belongs to a group of dramas written by Słobodzianek after the Drama Laboratory workshop in Nasutów near Lublin (July 2007). The main topic of the workshop was the history of Lublin Jews. The play was first presented to the public at a reading during the Konfrontacje Theatre Festival in Lublin in 2008, which was also 
devoted to Jewish themes and Polish-Jewish relations. From the very beginning, our Class has been interpreted as a historical or even political drama, referring primarily to the history of Polish-Jewish relations and their place in the collective memory. But it can also be interpreted more universally as a work on the individual and collective psychological mechanisms that underlie the gamut of human prejudice: from arguments at the school academy to pogroms and wars; from hate speech to torture and murder; from (not only antisemitic) stereotypes to mass dehumanisation. The connection between the story told by Słobodzianek and the discussion around Jan Tomasz Gross' book was obvious for the readers and the viewers of the play, and it strongly influenced its reception. Anna Bikont, a Polish journalist who has written several books reconstructing the events in Jedwabne, took exception with Słobodzianek's portrayal of the historical figures involved in the massacre, in particular Zygmunt Laudansky, who was one of the most active participants. According to Bikont, the portrayals were too approximate, and in some cases too positive, criticisms not uncommon to the critical reception of plays based on the massacre of Jews committed by Poles during the war. Our Class might be seen as an example of theatre as ritual, in which collective memory and confrontation with death play a major role. It is also a theatre of "semiotic obsession", as Grzegorz Niziołek describes it: "everything here is a sign, everything means something, everything is interwoven with everything, it combines, complements and counterpoints everything” (Niziołek, 2013, p. 542).

\section{Cited Works}

Meisel, M. (2013). Our Class: Theater Review. The Hollywood Reporter (4.16.2013), online: www.hollywoodreporter.com/review/class-theater-review-440477 [Accessed: 04.07.2019]. Niziołek, G. (2013). Polski teatr Zagłady. Warszawa: Wydawnictwo Krytyki Politycznej. Słobodzianek, T. (2009). Nasza klasa: historia w XIV lekcjach. Gdańsk: Wydawnictwo Słowo/Obraz Terytoria.

\section{Further References}

Bereta, K. (2000). Tadeusz Słobodzianek - szkic do portretu. Litteraria, (31), pp. 175192. Cavendish D. (2009), Is Our Class in National Theatre Really Such A Reliable History Lesson? Daily Telegraph, 9.11.2009. Cieński, M. (1995), Słobodzianek: powtórzenie. Notatnik Teatralny, 5(16), pp. 52-59. Chojka, J. (1995). Koniec wieku według Tadeusza Słobodzianka. Dialog, (11), pp. 120-126. Czaja M. (1997). Święci grzesznicy. Bohaterowie Tadeusza Słobodzianka pomiędzy rajem i piekłem. Dramaturgia Polska, 4-5, pp. 98-99. Czaja, M. (2000). Eschatologiczne gry Tadeusza Słobodzianka. Dialog, (9), pp. 131-143. Czaja, M. (2002). Koniec świata, choroba i sąd ostateczny (Apokaliptyczne historie Tadeusza Słobodzianka). Konteksty, (3-4), pp. 249-263. Duniec, K., Krakowska, J. (2011). Nasza klasa, czyli słuszna sprawa. In: T. Majewski, A. ZeidlerJaniszewska, eds., Pamięć Shoah. Kulturowe reprezentacje i praktyki upamiętnienia. Łódź: Wydawnictwo Officyna, p. 931. Krupa, B. (2013). Opowiedzieć Zagładę. Polska 
proza i historiografia wobec Holocaustu (1987-2003). Kraków: Universitas. TokarskaBakir, J. (2010). Nasza klasa na wspak. Dwutygodnik, (42). Available online: www. dwutygodnik.com/artykul/1532-nasza-klasa-na-wspak.html [Accessed: 07.07.2019].

$\mathrm{AF}$ 